DOI https://doi.org/10.18551/rjoas.2017-11.08

\title{
FOREIGN EXPERIENCE OF PUBLIC-PRIVATE PARTNERSHIP'S PROJECTS IMPLEMENTATION: PROSPECTS FOR RUSSIA
}

\author{
Komissarova V.V., Lecturer \\ Vladivostok State University of Economics and Service, Vladivostok, Russia \\ E-mail: valeriya.komissarova@vvsu.ru
}

\begin{abstract}
In the article the author analyzes the foreign experience of implementing projects within the public-private partnership framework and considers the possibilities of its application in Russia. In the modern understanding, public-private partnership is understood as an institutional and organizational alliance between the state and business in order to implement national and international, large-scale and local, but always socially significant projects in a wide range of activities: from the development of strategically important industries and science research and development to the provision of public services. As a rule, such alliance is temporary, as it is created for a certain period of time in order to implement a particular project and ceases to exist after its implementation.
\end{abstract}

\section{KEY WORDS}

Public-private partnership, models, industry, infrastructure, investments, government programs, non-governmental funding, private business, privatization, economic potential.

Today the organization of interaction between the public sector and entrepreneurial structures is one of the main ways that can ensure the growth of the investment potential of the socio-economic sphere of management. That is why the question of financing infrastructure development projects in conditions of limited possibilities of state budgets and unused resources of private business remains one of the topical areas of research.

Interest in public-private partnership as a form of cooperation between state and business structures for the development, planning, financing, construction and operation of infrastructure is due to the fact that the purpose of this cooperation is the implementation of national and international socially significant projects in various fields of activity on a longterm basis, the pooling of resources and the sharing of risks among participants [1].

The prerequisite for creating a PPP was the belief that private business is more mobile, and therefore operates more efficiently than state structures. The main areas of application of partnerships were, first of all, those that traditionally belonged to the jurisdiction of the state. For example, public goods, such as transportation, communal, social infrastructure, cultural facilities, public services - the maintenance of public facilities, utilities, environmental facilities, law enforcement services, social facilities - education, health, social protection [2]. Analyzing the experience of developed and actively developing countries in the sphere of construction, maintenance and operation of infrastructure facilities, it is possible to follow changes in such sectors as road and municipal services, railway and pipeline transport, electric power industry, seaports, and airports formerly owned by the state. The reason for these changes was, on the one hand, the lack of funds in state budgets, not only for further development, but also for the simple maintenance of these industries, and on the other, the inability to privatize these sectors because of their strategic, social and socio-political significance. The emerging contradiction served as a basis for the creation and introduction into business practice of the concept of public-private partnership [3]. This system of relations between the state and private business arose as a result of many years of searching for ways to improve the quality of public services while reducing the country's budget expenditures for these purposes.

The sectors of this form partnership application vary by country, and the leading positions are taken by projects for the creation and development of energy and transport infrastructure. According to the World Bank the most frequently implemented public-private 
partnership projects in the energy sector were $41 \%$ of the total number of projects, $27 \%$ in the transport and road sector, $17 \%$ in the field of communications, $15 \%$ in providing water supply and development of sewage and treatment systems in low- and middle-income countries from 1990 to 2016 [4].

The cooperation attractiveness within the framework of public-private partnership lays in the possibility each participant strengths combining. This is the legal authority, protectionist procurement policy, the balance of goals to meet public needs, labor and capital resources for the public sector, and - management effectiveness, the latest technologies, efficient production facilities, cash management experience, staff development, integrated resource use - for the private one.

Thus, the public-private partnership mechanism allows to unite the strong positions of each side [5].

At the same time, this system of relations causes many disputes among scientists and practitioners. To date, there is no specific definition, no single understanding of the essence of public-private partnership. Thus, some experts consider public-private partnership as a form of indirect privatization on the grounds that the advanced economies experience often indicates a redistribution of powers between the state and private business, with the broad powers transfer, related to the ownership, operation, construction and financing of facilities. In this case, cases of subsequent partial or complete privatization of such objects are not uncommon.

Other scientists consider PPP as a special, full-fledged form of state facilities privatization replacement, which allows, on the one hand, to realize the entrepreneurial initiative potential of private capital, on the other hand, to retain state's control functions in socially significant sectors of the economy. At the same time, the state remains the owner of the objects, attracting private capital to solve a variety of problems [6].

Contradictions in understanding the partnership essence and the indistinctness of formulations served as a prerequisite for the key principles formation on which the term PPP understanding in the world practice is based. As a rule, they are usually referred to as:

1. Public-private partnership assumes official relations or arrangements between public and private participants, which are fixed in official documents, in particular in regulatory legal acts, that is, they form special legal institutions;

2. Bodies of state and municipal management act in PPP projects not like as a regulator, but as an equal partner for a private investor, who does not seek to realize his power over him;

3. First of all, public-private partnership projects are aimed to realize public interests, which are formed on the basis of nation-wide public benefit goals;

4. The nature of joint actions is inherent for public-private partnership, when the state and the private investor jointly attract resources, make decisions in the process of financing and managing the project [7].

To decide whether to use one of the public-private partnership mechanisms for the project implementation, the state proceeds from two points of view. The first point is based on a financial approach - when the objective is to use private capital to meet infrastructure needs, the second one - on the operational approach - when the goal is to optimize time and efficient allocation of costs in the operation of the facility. This is a determining factor in the choice of the public-private partnership scheme, which differ from each other, mainly, the share of risk transferred to the private sector, the volume of each party's investment, control over various types of work and ownership of assets.

Legal public-private partnership models may be different, but the state's primary role in budget instruments using, public property, legislative regulations and other public prerogatives to manage a portion of project risks that private participants can't bear remains unchanged.

Examples of successful cooperation between the state and business structures are functioning public infrastructure facilities, both in developed and developing countries.

The largest practical experience in realizing a partnership between the state and the private sector has been accumulated in the USA, Canada and Australia, where PPP 
development concepts are included in government programs [8]. One of the most famous public-private partnership successful implementation examples is the creation in the United States of the Interstate Highway System.

The project duration was 17 years (from 1956 till 1973), estimated cost - USD \$129 billion, and the total length of the constructed roads exceeded 90,000 kilometers (high-speed toll roads over 9,000 kilometers). In addition to the construction of highways, the USA is implementing projects in the field of energy, municipal economy, and IT systems.

Table 1 - The main (basic) public-private partnership models classification

\begin{tabular}{|c|l|}
\hline PPP Model & \multicolumn{1}{c|}{ The main characteristics } \\
\hline $\begin{array}{c}\text { Construction-operation-transfer } \\
\text { (BOT-Build, Operate, Transfer) }\end{array}$ & $\begin{array}{l}\text { Used mainly in concessions. Infrastructure is created due to the } \\
\text { concessionaire, which after the completion of operation acquires } \\
\text { the right to build facility within the period allotted for recoupment of } \\
\text { invested funds. After the object is passed to the state. }\end{array}$ \\
\hline $\begin{array}{c}\text { Build-own-operate-transfer/management } \\
\text { (BOOT-Build, Own, Operate, Transfer) }\end{array}$ & $\begin{array}{l}\text { In this case, the private partner receives the authority to not only } \\
\text { use, but also ownership of the object during the term of the } \\
\text { agreement, after which it passed into the ownership of the State. }\end{array}$ \\
\hline $\begin{array}{c}\text { Build-transfer-operate/manage } \\
\text { (BTO-Build, Operate, Transfer) }\end{array}$ & $\begin{array}{l}\text { This mechanism involves the transfer object state immediately upon } \\
\text { completion. He then goes into the usage of the private partner, but } \\
\text { without the right of ownership to it. The term of the agreement shall } \\
\text { be sufficient to the private partner failed to recoup their investments. }\end{array}$ \\
\hline $\begin{array}{c}\text { Build-own-operate/manage } \\
\text { (BOO-Build, Own, Operate) }\end{array}$ & $\begin{array}{l}\text { The object created by the expiration of the agreement is not } \\
\text { transferred to the public authorities, and remain at the disposal of } \\
\text { the private partner. }\end{array}$ \\
\hline $\begin{array}{c}\text { Construction-operation-transfer service } \\
\text { (BOMT-Build, Operate, Maintain, Transfer) }\end{array}$ & $\begin{array}{l}\text { The private partner is responsible for the content and maintenance } \\
\text { of built infrastructure for them. }\end{array}$ \\
\hline $\begin{array}{c}\text { Design-build-own-operate- } \\
\text { transfer/management }\end{array}$ & $\begin{array}{l}\text { The peculiarity of this agreements type is the responsibility of the } \\
\text { private partner, not only for the infrastructure construction of the } \\
\text { object, but also for its design. }\end{array}$ \\
$\begin{array}{c}\text { (DBOOT-Design, Build, Own, Operate, } \\
\text { Transfer) }\end{array}$ & $\begin{array}{l}\text { The works complex on designing, construction, operation and } \\
\text { financing of the private sector totally portable (concessionaire), and } \\
\text { the owner is the state. Source of income for the private sector, most } \\
\text { often in this case, the fee will be the direct beneficiaries of this } \\
\text { object. }\end{array}$ \\
\hline $\begin{array}{l}\text { Design-build-finance-operate/manage } \\
\text { (DBFO Design, Build, Finance, Operate) }\end{array}$
\end{tabular}

Source: Compiled by the author according to the «User Guidebook on Implementing Public-Private Partnerships for Transportation Infrastructure Projects in the United States» and the Toolkit for Public-Private Partnerships in the Road Sector PPIAF.

In Canada, public-private partnership energy sector projects are successfully and most frequently implemented. However, public-private partnership in Canada is not limited to this direction only. An example of public-private partnership in the road sector is the construction of the ring road South East Edmonton Ring Road (Anthony Henday Drive). During the project implementation, 11 kilometers of the road were built with the number of lanes from 4 to $6 ; 24$ bridges, 5 traffic interchanges, 3 overpasses, and 3 overpasses over the highway. The project was implemented in PPFO public-private partnership contract accordance. Funds for the project construction were allocated by the Government of Canada and Alberta from the Canadian Strategic Infrastructure Fund (Canada Strategic Infrastructure Fund - CSIF). Through this Fund, the Government of Canada works with the local government, as well as with private sector enterprises involved in infrastructure projects. The Fund supports largescale projects aimed at strategic development, improving the quality of life and ensuring economic growth.

To implement the project, a private partner contract was concluded for 30 years, and the contract value was $\$ 493$ million.

In Australia, it is possible to single out the construction of a desalination plant among the large public-private partnership projects currently being implemented. The project cost is 3.1 billion Australian dollars was launched in 2007 as part of the state program «Our water is our future». To implement the project, a consortium of private companies was established to provide financing, construction, operation and maintenance of the plant. Another major 
project is the construction of the «East Link» highway cost of 2.5 billion Australian dollars. For the purposes of the project, a consortium with the participation of «Masquarie Bank» (project financing), «Thiess and John Holland» (TJH) (construction), «Sociedad Iberica de Construccioness Electricas, SA» (road equipment), «Transfield Services Pty Ltd» (exploitation and technical support).

In China the active area of public infrastructure construction is the environmental infrastructure expansion, which includes water channels and wastewater treatment. Cooperation examples in this area include the 6th water treatment plant in Chengdu, the Northern sewage treatment plant in Shenyang and the wastewater treatment facilities in Beijing.

Also, public-private partnership mechanisms were successfully used in the construction of infrastructure facilities for the Olympic Games in Beijing, the gas project «lzhuang», the Beijing Metro, the «Laibin B Power Plant» in Guangqi Province, which was built with the foreign investment participation.

The Government of India, setting priorities for cooperation between the state and business, pays special attention to the country's infrastructure development. The total cost of the project for the construction of the first private water pipe in Tirupur (Tamil Nadu) exceeded \$ 230 million. To implement it, the Water Investment Company (Tamil Nedu Road Development Company) was based in the form of a joint venture between the state government and IL\&FS company. Also within PPP project a 95-kilometer 6-lane MumbaiPuni highway was built cost of $\$ 400$ million; along with P\&O Australia and Jawaharlal Neru Port Crust, a two-stage sea container terminal Nhava Sheva was built. Among the successfully implemented national projects to modernize the airport infrastructure is the construction of terminals in the international airports of Bangalore, Hyderabad, Delhi and Mumbai.

Most public-private partnership projects around the world are quite capital intensive, so they are funded not only by attracted investors private capital, but also from other sources. This can be the placement of government orders financed from budgets of different levels, budget subsidies for partial financing of the project, provision of benefits (tax, administrative) from the state, issuance of government debt obligations [9].

Special attention should be paid to studying Russian experience in implementing PPP projects. The public-private partnership projects market development in Russia has only 6-7 years of history that definitely limits the number of successful projects, which, as a rule, are provided by the local authorities' own initiative and small in scale. The main models of regional public-private partnership projects are long-term leasing with the reconstruction condition, concession agreements, agreements on the development of the special economic zones (SEZ), agreements on the use of the Investment Fund, production sharing agreements, and others.

Most of the projects, such as the «Integrated Program for Construction and Reconstruction of Water Supply and Sanitation Facilities in the City of Rostov-on-Don and the South-West of the Rostov Region», the construction of the «Western High-Speed Diameter Motorway» in St. Petersburg, the establishment of a solid waste processing plant in the village of Yanino and others is in the stage of «current» projects.

To ensure the effective public-private partnership projects implementation in Russia, attention should be paid to the number of generally applicable conditions provision: unified project management system for public-private partnerships creation, including regulatory and legal support and the relevant institutional environment; the financing mechanisms development for various options of interaction between the state and private capital, including the state guarantees provision, as well as tax incentives for private investors involved in the major projects implementation; ensuring macroeconomic stability and stimulating the market environment development; a serious anti-corruption drive in the government; state structures experience and knowledge adoption for training specialists in state structures; proper execution of government property documents transferred to private capital management; well-considered approach in the risks allocation among the public- 
private partnership project participants; ensuring a serious state expertise documentation submitted by potential private partners for the correspondence of its actual situation.

Today, Russia needs to adopt the long-standing positive experience of private capital attracting, effective management and modern technologies in order to create an economic and organizational legal mechanism in the country that would ensure the interest of private investors and a fair procedure for their competitive selection, reduce total public costs and production risks.

Conclusion. Public-private partnership worlds experience analysis in the projects implementation shows that the development of public-private relations on the principles of PPP fully justifies itself, contributing to the development of socially significant infrastructure and the achievement of a positive social effect at the state level. On the one hand, this type of partnership provides private partners with a long-term stable business, improving the company's image and obtaining additional opportunities for business development.

The state, by attracting non-governmental funding, reduces the costs of construction, maintenance and operation of infrastructure facilities and ensures cost-effective project management by transferring management functions to a private investor has the ability to attract modern high-performance technologies, improve the investment climate and obtain additional political «points» if the object has social significance.

Along with the cooperation schemes advantages between the state and private business, there are a number of issues that require more detailed research to improve the system of these relationships. The priority areas of study include combining the commercial motivation of the private sector with the needs of public organizations, the most rational and acceptable distribution of risks, managing partnerships through agreements within 20-30 years in a rapidly changing environment, an adequate evaluation of projects over 20 years and the classification of proposals in public-private partnership in terms of their effectiveness.

In connection with above-mentioned, author can conclude that further effective functioning of developed and developing countries' economies, active use forms of publicprivate partnership forms is necessary, which has already become one of the main instruments of public administration in the world. The last twenty years events have definitely shown that the private entrepreneurship economic potential and the state's possibilities integration is necessary to solve the most complicated socioeconomic, structural, technological and other strategic tasks of the countries development, to realize their national interests and to ensure an enabling environment for life activity.

\section{REFERENCES}

1. Varnavsky V.G. (2005) Partnership of the state and private business: forms, projects, risks. M., Science.

2. Hayrapetyan M.S. (2010) Foreign experience of using public-private partnership [Electronic resource] // Legal portal of the «Arkon Group» URL: http://arkon-group.ru

3. Nikolaeva L.A., Komissarova V.V. (2011) Leasing as a form of financing innovative projects in the road economy // Transport business of Russia. No. 1. pp. 32-37

4. Private Participation in Infrastructure (2016) [Electronic resource] // Official site of the World Bank Group URL: http://ppi.worldbank.org/explore/ppi_exploreRankings.aspx

5. Norment R. (2007) Fundamentals of Public-Private Partnerships (PPPs) [Electronic resource] // Official site of the «NCPPP» URL: http://www.ncppp.org/resources/

6. Bondar N.N. (2010) Experience of public-private partnership in the transport sector: achievements and setbacks [Electronic resource] // Legal portal of the «Arkon Group» URL: http://arkon-group.ru/see.php?see=53

7. Analytical report on the results of the study (2010) «Development of public-private partnership in the regions of the Central Federal District: investment and infrastructure», Public-Private Partnership Development Center

8. Dynkin A.A. (2008) World economy: forecast to 2020 // IMEMO RAS.

9. Overview of Key Elements and Sample Provisions State PPP Enabling Legislation for Highway Projects (2010) // Official site of the «Nossaman» URL: http://www.fhwa.dot.gov 